\title{
Solitary intraosseous neurofibroma of the mandible. Apropos of a case
}

\author{
Javiera Deichler ${ }^{1}$, René Martínez ${ }^{1}$, Sven Niklander ${ }^{1}$, Heraldo Seguel ${ }^{2}$, Maureen Marshall ${ }^{1}$, Alfredo Esguep ${ }^{3}$
}

${ }^{1}$ Surgery and Oral Pathology Department Instructors, University Andrés Bello

${ }^{2}$ Maxillofacial Surgeon, Naval Hospital Admiral NEF

${ }^{3}$ Professor of Oral Pathology, University Andrés Bello. MSc University of London

Correspondence:

Av Valparaíso 1560

Viña del Mar, Chile

j.deichler@hotmail.com

Deichler J, Martínez R, Niklander S, Seguel H, Marshall M, Esguep A. Solitary intraosseous neurofibroma of the mandible. Apropos of a case. Med Oral Patol Oral Cir Bucal. 2011 Sep 1:16 (6):e704-7.

Received: 22/02/2010 http://www.medicinaoral.com/medoralfree01/v16i6/medoralv16i6p704.pd

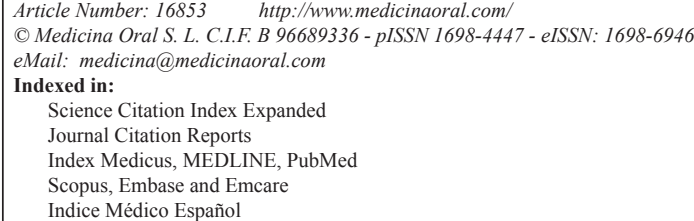

\begin{abstract}
Neurofibroma is a benign neoplasm derived from peripheral nerves. Most of these are associated with Neurofibromatosis but may also occur as solitary lesions. When found on the head and neck they are generally located in the soft tissue. Intraosseous location is very rare.

The following report describes a case of an intraosseous neurofibroma located in the left mandibular ramus of a 14-year-old child. The patient did not had clinical evidence of the lesion and it was found on a routine radiographic examination. Surgical excision of the lesion was scheduled and the sample was submitted to histopathological study. Representative sample cuts were studied using conventional techniques of hematoxylin-eosin and immunohistochemistry using primary antibodies anti S-100 protein, vimentin, and neuroespecific enolase.

A review of clinical, radiographic, histologic and immunohistochemical features of other cases of intraosseuos neurofibromas located in the jaws together with the possible differential diagnosis of the lesion are discussed.

Our case corresponds to a intraosseous neurofibroma of controveltial diagnosis because even though it presents typical neurofibroma histomorphological features it has immunophenotype different from usual.
\end{abstract}

Key words: Neurofibroma, benign intraosseous tumor, tumor of neural origin.

\section{Introduction}

Neurofibroma (NF) is a benign tumor of neural origin derived from the peripheral nerve sheath (1-5) that may have variable histology. Some authors, such as Rosenbaum, propose Schwann cells as the precursors of neurofibroma (1). Others, however, acknowledge that this tumor may be composed of a varying number of cells, among which are recognized the Schwann cells, perineural cells, fibroblasts and intermediate cells (6).
Benign tumors of peripheral nerve sheath, particularly neurofibromas, often locate in the soft tissue of the head and neck. However, there are very few reports of intraosseuos neurofibromas. This can be explained because bone marrow spaces don't have nerve sheaths or myelinated nerves. Most neurofibromas occur in the mandible, and no more than 50 cases, inlcuding this one, have been published so far (7). 


\section{Case Report}

A 14-year old male patient consulted for orthotontic treatment. In the initial evaluation an orthopantomograph was taken. It revealed a unilateral radiolucency in the right mandible ramus, extending verticaly up to the basal border of the mandible. Horizontaly, the lesion occupied the whole width of the ramus. The radiographically boundaries of the lesion were well defined, not corticalized, with scalloped borders, The lesion was partially proyected over the follicle of the 3.8 tooth. There was no vertical displacement of the mandibular canal or the tooth germ 3.8. (Fig. 1)

Intraoral examination revealed no clinical changes associated with the lesion. Bone outlines were normal to palpation and the patient reported no symptoms.

Based on the clinical and radiographic findings, a ketarocyst, ameloblastoma and ameloblastic fibroma were proposed as provisional diagnosis. A surgical excision was planned under general anesthesia, for curetage and histopathologic study.

Gross examination showed a laminar, rectangular soft tissue mass, firm and white-grayish, which measured $4 \times 1,5 \times 0,5 \mathrm{~cm}$, with no internal calcifications.

Microscopic study with hematoxilyn-eosin (HE) showed a tumour mass formed by regular spindle cells, with wavy, hiperchromatic nuclei and scanty cytoplasm,

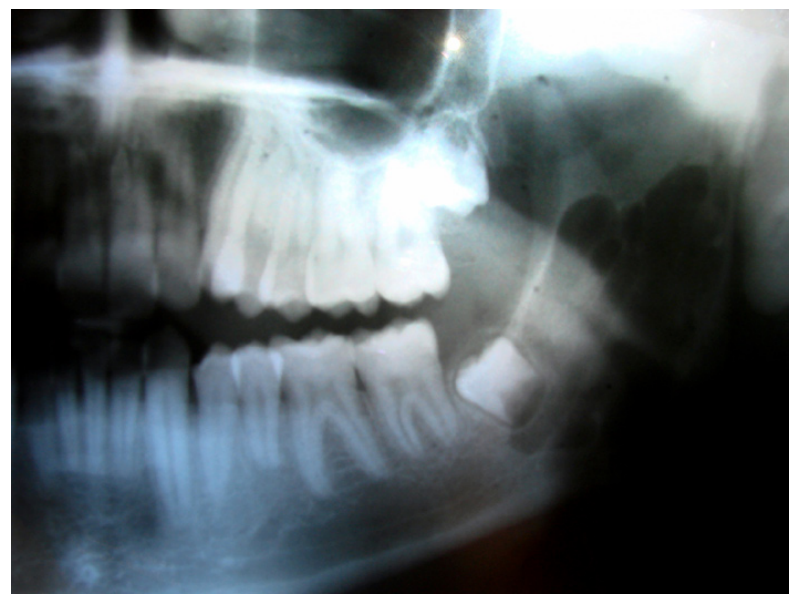

Fig. 1. Panoramic x-ray.

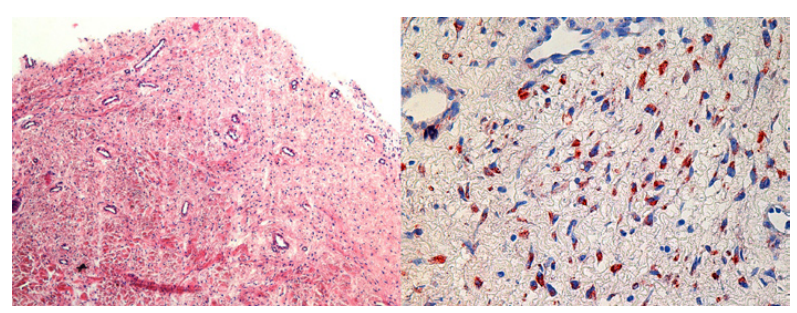

Fig. 2. On the left we see the histopathology of neurofibroma, seen with $10 \mathrm{X}$ and on the right is the immunohistochemistry positive for NSE, seen with $40 X$. in a richly vascularized myxoide stroma, with presence of collagen fibers and conective tissue cells. There were also nerve bundles cut transversely (Fig. 2). Representative sample cuts were studied with immunohistochemistry using primary antibodies anti S-100 protein, vimentin, and neuroespecific enolase (NSE). The process was perfomed following the standard protocol, using positive and negative controls. Immunohistochemistry showed that tumor cells were positive for vimentin, NSE (Fig. 2) and negative for S-100 protein. The residual nerve fibers were positive for S-100 protein and NSE. Considering the tumor's histopathological features with $\mathrm{HE}$ and immunohistochemistry, intraosseous neurofibroma was diagnosed., even though it might be controversial the fact that it was negative to immunostaining for S-100. It is important to considerer the differential diagnosis with other neoplasm arising from peripheral nerve sheath, such as schwannoma, perineuroma, neurofibrosarcoma and, less frecuently, witn mesenchymal tumor of muscular or myxoid nature.

\section{Discussion}

Nerve sheath tumors located in the jaw are extremely rare, having published only a few cases of central neurofibroma of the mandibule (4). (Table 1) presents the clinical, radiographic, histological and immunohistochemistry features of the intraosseous neurofibroma of the jaws cases published.

The average age is 27.5 years, ranging between 14 and 45 years old $(8,9)$, and there is no clear evidence as to the sex distribution. In our case, it was a 14 years old man.

Ninety percent of the neurofibromas are associated with neurofibromatosis type $1(2,3,8-12)$, so the presence of a solitary case requires physical examination and family history so as to exclude the disease. In this case, there were no clinical signs or family history suggestive of neurofibromatosis. The lesion was a solitary one

As Polak et al. (5) pointed out, it is important to hightlight the need to rule out the differential diagnosis of schwanomma (Antoni A and Antoni B areas) and perineuroma (pattern similar to onion bulbs), as proposed by Ide.

Ide, Shimoyama and Gomez and Oliveira $(6,13)$ also recognized that neurifibroma is composed of a complex proliferation of schwann cells, perineural cell, endoneural fibroblasts and intermediate cells. These authors distinguished three types of neurofibromas (NF type I, II, and III) based on their reactivity to different markers and ultrastructural features. This subdivision is usefull and represents the variable possibility for different markers.

This case should be considered as a intaosseous neurofibroma of controversial diagnosis because it showed no histological or immunohistochemistry features typical 
Table 1. Clinical, radiographic, histological and immunohistochesmistry features of the intraosseous neurofibroma of the jaw cases.

\begin{tabular}{|c|c|c|c|c|c|c|c|}
\hline Reference & Age & Gender & Location & $\begin{array}{l}\text { Symptom } \\
\text { atology }\end{array}$ & $\begin{array}{c}\text { Radiographic } \\
\text { Features }\end{array}$ & $\begin{array}{l}\text { Histologica } \\
\text { Featuresl }\end{array}$ & $\begin{array}{c}\text { Immunohisto } \\
\text { chemistry } \\
\text { Features } \\
\end{array}$ \\
\hline $\begin{array}{l}\text { Vivek and } \\
\text { cols. (11) }\end{array}$ & 39 years & $\mathrm{F}$ & Mandible & No & $\begin{array}{l}\text { Well- } \\
\text { circumscribed } \\
\text { radiolucent } \\
\text { area with } \\
\text { continuity loss } \\
\text { of the } \\
\text { mandibular } \\
\text { canal }\end{array}$ & $\begin{array}{l}\text { Spindle cells with } \\
\text { wavy nuclei } \\
\text { arranged in the } \\
\text { form of booklets }\end{array}$ & $\begin{array}{l}\text { Anti S-100 } \\
\text { Positive }\end{array}$ \\
\hline $\begin{array}{l}\text { Larsson and } \\
\text { cols. (2) }\end{array}$ & 46 years & M & Mandible & $\begin{array}{l}\text { Intermitte } \\
\text { nt pain }\end{array}$ & $\begin{array}{c}\text { Bone } \\
\text { destruction } \\
\text { with slightly } \\
\text { radiopaque } \\
\text { areas } \\
\end{array}$ & $\begin{array}{l}\text { Spindle cell with } \\
\text { elongated or oval } \\
\text { nuclei forming } \\
\text { cords }\end{array}$ & Not perfomed \\
\hline $\begin{array}{l}\text { Larsson and } \\
\text { cols. (2) }\end{array}$ & 25 years & $\mathrm{F}$ & Mandible & No & $\begin{array}{l}\text { Extense bone } \\
\text { resorption }\end{array}$ & $\begin{array}{l}\text { Irregular nerve } \\
\text { fiber strands } \\
\text { intermigled with } \\
\text { collagen fibers } \\
\text { and abundant cells }\end{array}$ & Not perfomed \\
\hline $\begin{array}{l}\text { Polak and } \\
\text { cols. (5) }\end{array}$ & 60 years & M & Mandible & No & $\begin{array}{l}\text { Unilocular } \\
\text { radiolucency }\end{array}$ & $\begin{array}{l}\text { Cords of fusiform } \\
\text { or ovoid cells } \\
\text { intermixed with a } \\
\text { fibrillary stroma }\end{array}$ & $\begin{array}{l}\text { Anti S-100 } \\
\text { Positive } \\
\text { Anti- Lai } 7 \\
\text { Positive } \\
\end{array}$ \\
\hline $\begin{array}{l}\text { Sharma and } \\
\text { cols. }(8)\end{array}$ & 5 months & $\mathrm{F}$ & Maxilla & No & No & $\begin{array}{c}\text { Cords of dense } \\
\text { collagen fibers } \\
\text { intermixed with } \\
\text { strands of nerve } \\
\text { tissue with wavy } \\
\text { nuclei } \\
\end{array}$ & $\begin{array}{l}\text { Anti S-100 } \\
\text { Positive } \\
\text { EMA } \\
\text { Negative }\end{array}$ \\
\hline $\begin{array}{l}\text { Mori and } \\
\text { cols. (3) }\end{array}$ & 18 years & $\mathrm{F}$ & Maxilla & $\begin{array}{l}\text { Tooth } \\
\text { mobility }\end{array}$ & $\begin{array}{l}\text { Well- } \\
\text { circumscribed } \\
\text { multilocular } \\
\text { radiolucency }\end{array}$ & $\begin{array}{l}\text { Growth of wavy- } \\
\text { like tumor cells in } \\
\text { a myxomatous } \\
\text { matrix }\end{array}$ & $\begin{array}{l}\text { Anti S-100 } \\
\text { Positive }\end{array}$ \\
\hline $\begin{array}{c}\text { Skouteris } \\
\text { and cols. (9) }\end{array}$ & 16 years & $\mathrm{F}$ & Maxilla & No & $\begin{array}{c}\text { Poorly- } \\
\text { defined } \\
\text { radiolucent } \\
\text { lesion } \\
\end{array}$ & $\begin{array}{l}\text { Spindle cells and } \\
\text { abundant } \\
\text { myxomatous } \\
\text { stroma }\end{array}$ & Not perfomed \\
\hline $\begin{array}{l}\text { Apostolidis } \\
\text { and cols. (4) }\end{array}$ & 67 years & $\mathrm{F}$ & Mandible & $\begin{array}{l}\text { Paresthesi } \\
\text { a and } \\
\text { hyperesth } \\
\text { esia }\end{array}$ & $\begin{array}{l}\text { Circumscribed } \\
\text { elliptical } \\
\text { radiolucency } \\
\text { with } \\
\text { expansiono f } \\
\text { the } \\
\text { mandibular } \\
\text { canal }\end{array}$ & $\begin{array}{l}\text { Numerous spindle } \\
\text { cells in a myxoid } \\
\text { matrix }\end{array}$ & Not perfomed \\
\hline $\begin{array}{l}\text { Poupard and } \\
\text { cols. (12) }\end{array}$ & 14 years & M & Maxilla & No & $\begin{array}{c}\text { Poorly } \\
\text { defined } \\
\text { radiolucency }\end{array}$ & $\begin{array}{c}\text { Spindle and } \\
\text { estellate cells with } \\
\text { a mucoid } \\
\text { extracellular } \\
\text { material with } \\
\text { some } \\
\text { condensation of } \\
\text { fibrous tissue }\end{array}$ & $\begin{array}{l}\text { Anti S-100 } \\
\text { Positive }\end{array}$ \\
\hline
\end{tabular}

F: female, M: male. 
of NF. Although positivity for neuroespecific enolase shows the presence of nerve tissue, negativity fo S-100 protein rules out the neural origin of cells observed in the tumor. This may be because the cells have a maturity level in which do not reflect the characteristics immunophenotype of neural origin cells (6). Despite the above and considering the histomorphological architecture of the lesion, the anatomic area (periphery of the inferior alveolar nerve), the delimitation and biological behavior, suported by the opinion of several pathologists, we confirm the diagnosis of neurofibroma.

It is important to consider that the solitary intraosseous neurofibroma may be the first manifestation of neurofibromatosis $(3,12)$. It is also necessary to conduct a clinical and radiographic follow-up, since recurrence and malignant changes have been reported (3).

\section{References}

References with links to Crossref - DOI

1. Rosenbaum T, Rosenbaum C, Winner U, Müller HW, Lenard HG, Hanemann CO. Long-term culture and characterization of human neurofibroma-derived Schwann cells. J Neurosci Res. 2000;61:52432 .

2. Larsson A, Praetorius F, Hjörting-Hansen E. Intraosseous neurofibroma of the jaws. Int J Oral Surg. 1978;7:494-9.

3. Mori H, Kakuta S, Yamaguchi A, Nagumo M. Solitary intraosseous neurofibroma of the maxilla: report of a case. J Oral Maxillofac Surg. 1993;51:688-90.

4. Apostolidis C, Anterriotis D, Rapidis AD, Angelopoulos AP. Solitary intraosseous neurofibroma of the inferior alveolar nerve: report of a case. J Oral Maxillofac Surg. 2001;59:232-5.

5. Polak M, Polak G, Brocheriou C, Vigneul J. Solitary neurofibroma of the mandible: case report and review of the literature. J Oral Maxillofac Surg. 1989;47:65-8.

6. Ide F, Shimoyama T, Horie N, Kusama K. Comparative ultrastructural and immunohistochemical study of perineurioma and neurofibroma of the oral mucosa. Oral Oncol. 2004;40:948-53.

7. Che Z, Nam W, Park WS, Kim HJ, Cha IH, Kim HS, et al. Intraosseous nerve sheath tumors in the jaws. Yonsei Med J. 2006;47:26470 .

8. Sharma P, Narwal A, Rana AS, Kumar S. Intraosseous neurofibroma of maxilla in a child. J Indian Soc Pedod Prev Dent. 2009;27:62-4.

9. Skouteris CA, Sotereanos GC. Solitary neurofibroma of the maxilla: report of a case. J Oral Maxillofac Surg. 1988;46:701-5.

10. Huang GS, Lee CH, Lee HS, Chang WC, Juan CJ, Chen CY. Solitary intraosseous neurofibroma of the tibia. Skeletal Radiol. 2005;34:303-6.

11. Vivek N, Manikandhan R, James PC, Rajeev R. Solitary intraosseous neurofibroma of mandible. Indian J Dent Res. 2006;17:135-8.

12. Poupard RJ, Mintz S. Solitary intrabony neurofibroma of the maxilla. J Oral Maxillofac Surg. 1997;55:768-72.

13. Gómez-Oliveira G, Fernández-Alba Luengo J, Martín-Sastre R, Patiño-Seijas B, López-Cedrún-Cembranos JL. Plexiform neurofibroma of the cheek mucosa. A case report. Med Oral. 2004;9:263-7. 